\title{
STATEMENTS OF ECB OfFICIALS AND THEIR EFFECT ON THE LEVEL AND VOLATILITY OF THE EURO-DOLLAR EXCHANGE RATE
}

\author{
DAVID-JAN JANSEN \\ JAKOB DE HAAN
}

CESIFO WORKING PAPER NO. 927

CATEGORY 6: MONETARY POLICY AND INTERNATIONAL FINANCE APRIL 2003

Presented at CESifo Conference on Macro, Money \& International Finance, February 2002 


\title{
STATEMENTS OF ECB OFFICIALS AND THEIR EFFECT ON THE LEVEL AND VOLATILITY OF THE EURO-DOLLAR EXCHANGE RATE
}

\begin{abstract}
This paper studies the reaction of the mean and volatility of the euro-dollar exchange rate to statements of ECB officials during the first years of EMU. We focus on statements on monetary policy and the (potential) strength of the euro. We find that the Bundesbank has dominated the news coverage. We conclude that ECB statements have mainly influenced volatility. In some cases there are effects of statements on the level of the euro-dollar rate. Efforts to 'talk up' the euro have not been successful. There is also evidence of asymmetric reactions to news.
\end{abstract}

JEL Code: E50, F31.

Keywords: ECB, euro, foreign exchange, news approach.

David-Jan Jansen
De Nederlandsche Bank
Research Department
P.O. Box 98
1000AB Amsterdam
The Nederlands
d.jansen@dnb.nl

\author{
Jakob de Haan \\ University of Groningen \\ Department of Economics \\ P.O.Box 800 \\ G700 AV, Groningen \\ The Netherlands \\ j.de.haan@eco.rug.nl
}

The authors thank Lex Hoogduin, Elmer Sterken, Peter van Els and Peter Vlaar for useful comments and discussions. Comments from Frank Heinemann, Yin-Wong Cheung, Frank Westermann and other participants in the CESifo Area Conference on Macro, Money and International Finance (Munich, 21-22 February 2003) are also gratefully acknowledged. All remaining errors are our own. The views expressed in this paper do not necessarily coincide with those of De Nederlandsche Bank. 


\section{Introduction}

Currency markets are continuously flooded with information. In spite of intensive research, the adjustment of exchange rates to this stream of information is still not fully understood. Previous research on the reaction of exchange rates to new information has mainly focused on the effects of (scheduled) announcements of macroeconomic variables. Still, it is likely that the (expected) actions of a central bank also influence exchange rates, especially in the short run. The central bank may change interest rates and has the opportunity to intervene in foreign exchange markets. The use of these instruments may have important effects on the value of the currency. Central bankers may also try to affect exchange rates by their communications. There is, however, hardly any research explicitly analyzing the impact of statements by central bank officials, the studies by Tivegna (2001) and Fatum and Hutchison (2002) being exceptions.

This paper studies the effects of statements made by European Central Bank (ECB) officials on the level and volatility of the euro-dollar exchange rate for the period January 4, 1999 to May 17, 2002. This was a very turbulent period in which the depreciation of the euro was rather problematic for the ECB. Before its introduction the euro was widely expected to be a strong currency. Some even hoped (or feared) that the euro would compete with the dollar in its role as most important international currency (see Eijffinger and De Haan, 2000 for a discussion). ${ }^{1}$ As the new currency was an important symbol for the EMU, its decline led some people even to question the overall success of the EMU. Apart from this image problem, the extensive depreciation of the euro was also a serious threat to price stability in the euro area (see De Haan et al., 2003). After some time, the ECB reacted by intervening in the foreign exchange market to support the euro. The success of these interventions is under debate. ${ }^{2}$ Apart from interventions, the ECB has been very active to support the euro verbally ('talking up the currency'). As we will see, many ECB officials have publicly expressed the view that the euro was undervalued during the period under consideration.

The purpose of this paper is to investigate how central bankers' statements are related to daily exchange rate changes. We apply the so-called 'news' approach to test for effects of ECB statements. This approach rests on two assumptions (see e.g. De Grauwe et al., 1993): the exchange rate should be modeled as an asset price and expectations are formed rationally. These assumptions imply that only unexpected information or 'news' about fundamentals should change the exchange rate as all currently

\footnotetext{
${ }^{1}$ The exchange rate regime may also affect other financial markets. See, for instance, Cheung and Westermann (2001) who report that even though the introduction of the euro did not affect the relationship between German and US equity markets, the volality of the German stock index has fallen significantly since the introduction of the euro.

${ }^{2}$ Whereas many observers question the effectiveness of interventions, Fatum and Hutchison (2002) claim that the first of the four interventions that they identify had some success. See Sarno and Taylor (2001) for a review of the literature on foreign exchange interventions. A recent study finding support for the effectiveness of interventions is Fatum and Hutchison (2003). See also Frenkel et al. (2001). According to the survey of Cheung and Chinn (2000), traders in forex markets belief that interventions increase volatility. At the same time, they do not consider central bank interventions very successful.
} 
available information is already reflected in current prices. We use an EGARCH specification that allows us to test for effects on the mean as well as on volatility. Even though it has been found that 'news' is rapidly incorporated into exchange rates (see, e.g., Cheung and Chinn (2000) who find that forex traders believe that the bulk of the adjustment takes place even within just one minute after the release of new information), we use daily observations like Fatum and Hutchison (2002) and Galati and Ho (2002). This is justified, as we are mainly interested in the effectiveness of statements of ECB officials. If the effects of 'talking up the currency' can only be observed using higher frequency data, ECB statements cannot be considered a very powerful instrument to influence developments at the foreign exchange market.

We collected statements of various central bankers - including statements of officials of national central banks in the euro area - as reported by the Bloomberg News Service. We find that statements of Bundesbank officials outnumber those of other central bankers. Our results indicate that ECB statements have had a larger impact on volatility than on the level of the exchange rate. Efforts of the ECB to 'talk up' the currency have not been successful. Our results also indicate that there has been an asymmetric reaction to 'news': the market reacts differently to positive and negative 'news'.

The remainder of the paper is structured as follows. Section 2 discusses previous papers that study the relationship between 'news' and the exchange rate. Section 3 discusses our methodology and the data, while section 4 describes the statement data in detail. Section 5 presents the results. Section 6 offers some concluding comments.

\section{The effect of 'news' on exchange rates: a survey of the recent literature}

According to the efficient market hypothesis only unexpected information or 'news' should have an effect on the exchange rate. It is common to test for 'news' effects by estimating some version of equation $(1)^{3}$ :

$$
\mathrm{R}_{\mathrm{t}}=\alpha+\beta_{1} \mathrm{EX}_{\mathrm{t}}+\beta_{2} \mathrm{UX}_{\mathrm{t}}+\beta_{3} \mathrm{Z}_{\mathrm{t}}+\varepsilon_{\mathrm{t}}
$$

where $\mathrm{R}_{\mathrm{t}}$ is the exchange rate return (defined as first differences in the log of the exchange rate), $\mathrm{EX}_{\mathrm{t}}$ is a matrix with expectations, $\mathrm{UX}_{\mathrm{t}}$ is a matrix with 'news' variables, and $\mathrm{Z}_{\mathrm{t}}$ is a matrix with control variables ${ }^{4}$.

Table 1 summarizes various papers studying the effect of 'news' on exchange rates. We focus on the following elements: the choice of 'news', the manner in which 'news' is measured, the

\footnotetext{
${ }^{3}$ The idea that 'news' - that is, innovations in certain variables - causes the bulk of movements in exchange rates has a history going at least as far back as Frenkel (1981).

${ }^{4}$ Rigobon and Sack (2002) and Evans and Lyons (2003) advocate the use of a new approach, based on state dependent heteroscedasticity.
} 
econometric framework, and the frequency at which the exchange rate is sampled. It follows from Table 1 that:

- most papers focus on scheduled macroeconomic announcements,

- 'news' is measured by dummies or as the difference between expectation and realization,

- most studies employ either OLS or GARCH models,

- most researchers use high frequency data.

The earlier papers in this field use ordinary least squares regressions and generally do not include control variables. Hakkio and Pearce (1985) study short-run responses of spot exchange rates to three categories of economic announcements: money growth, inflation and real activity. They use survey results to proxy the expected part of the announcements. Their exchange rate series has three observations per trading day. These authors find that the exchange rate reacts to unexpected changes in the money stock. Ito and Roley (1987) study reactions of the yen-dollar exchange rate to 'news' from Japan and the U.S. They use intra-day data (four observations per trading day). These authors find that the yen-dollar exchange rate was mainly driven by 'news' from the U.S.

Improved data availability enabled researchers to use high frequency data in order to separate the effects of 'news' from the other factors influencing the exchange rate. Another innovation was the use of dummies to quantify 'news'. The papers of Ederington and Lee (1993) and Goodhart et al. (1993) combine these two aspects. Ederington and Lee (1993) examine the impact of nineteen types of scheduled macroeconomic announcements on the volatility of the U.S. dollar-German mark exchange rate. These authors use dummies that are equal to one when an announcement is made and zero otherwise. They find that the dollar-mark exchange rate is influenced by announcements on merchandise trade, employment, retail sales, the producer prices index and GNP. Goodhart et al. (1993) focuses on two particular events: a release of US trade figures and an interest rise in the UK. These authors conclude that these events significantly change the time-series behavior of the exchange rate.

The majority of the papers summarized in Table 1 focus on scheduled macroeconomic announcements. The papers by DeGenarro and Shrieves (1997), Tivegna (2001) and Fatum and Hutchison (2002) are exceptions. DeGenarro and Shrieves (1997) estimate the impact of market activity and 'news' on the volatility of the yen-dollar exchange rate. They use quote arrival as a proxy for market activity and the number of news headlines in the Reuters news service as a proxy for 'news'. These authors distinguish three categories: macroeconomic announcements, economic policy announcements and interest rate reports. The last two categories contain unscheduled 'news'. They conclude that both private information and 'news' are important determinants of exchange rate volatility. 
Table 1: Selected papers that test for news effects

\begin{tabular}{|c|c|c|c|c|}
\hline & News variables & $\begin{array}{l}\text { How news is } \\
\text { measured }\end{array}$ & Estimation framework & $\begin{array}{l}\text { Sampling frequency of } \\
\text { FX series }\end{array}$ \\
\hline $\begin{array}{l}\text { Hakkio and } \\
\text { Pearce } \\
(1985)\end{array}$ & $\begin{array}{l}\text { Announcements on } \\
\text { money, inflation and real } \\
\text { activity }\end{array}$ & $\begin{array}{l}\text { Difference between } \\
\text { expected and } \\
\text { announced value }\end{array}$ & $\begin{array}{l}\text { OLS estimation of } \\
\text { equation (1) }\end{array}$ & $\begin{array}{l}\text { Three spot rates per } \\
\text { day }\end{array}$ \\
\hline $\begin{array}{l}\text { Ito and Roley } \\
\text { (1987) }\end{array}$ & $\begin{array}{l}\text { Announcements on money } \\
\text { supply, industrial } \\
\text { production and producers } \\
\text { prices }\end{array}$ & $\begin{array}{l}\text { Difference between } \\
\text { expected and } \\
\text { announced value }\end{array}$ & $\begin{array}{l}\text { OLS estimation of } \\
\text { equation (1) }\end{array}$ & $\begin{array}{l}\text { Four segments per } \\
\text { business day }\end{array}$ \\
\hline $\begin{array}{l}\text { Goodhart et } \\
\text { al. (1993) }\end{array}$ & Two specific events & Dummies & $\begin{array}{l}\text { OLS and GARCH-M } \\
\text { framework }\end{array}$ & Continuous \\
\hline Ederington & Scheduled macroeconomic & Dummies & OLS & Five minute intervals \\
\hline $\begin{array}{ll}\text { and } & \text { Lee } \\
(1993) & \end{array}$ & news releases & & & \\
\hline $\begin{array}{l}\text { DeGennaro } \\
\text { and Shrieves } \\
(1997)\end{array}$ & $\begin{array}{l}\text { Scheduled macroeconomic } \\
\text { news, unscheduled } \\
\text { economic policy news and } \\
\text { interest rate reports }\end{array}$ & $\begin{array}{l}\text { Number of news } \\
\text { items }\end{array}$ & $\begin{array}{l}\text { ARMA with GARCH } \\
\text { errors terms }\end{array}$ & Ten minute \\
\hline $\begin{array}{l}\text { Andersen } \\
\text { and } \\
\text { Bollerslev } \\
(1998)\end{array}$ & $\begin{array}{l}\text { Scheduled macroeconomic } \\
\text { announcements }\end{array}$ & Dummies & $\begin{array}{l}\text { Simultaneous } \\
\text { modeling of intra- } \\
\text { daily and inter-daily } \\
\text { volatility } \\
\text { announcements }\end{array}$ & Five minute \\
\hline $\begin{array}{l}\text { Almeida et } \\
\text { al. (1998) }\end{array}$ & $\begin{array}{l}\text { Macroeconomic } \\
\text { announcements }\end{array}$ & $\begin{array}{l}\text { Difference between } \\
\text { expected and } \\
\text { announced value }\end{array}$ & $\begin{array}{l}\text { OLS estimation of } \\
\text { equation (1) }\end{array}$ & Five minu \\
\hline $\begin{array}{l}\text { Galati and } \\
\text { Ho (2001) }\end{array}$ & $\begin{array}{l}\text { Macroeconomic } \\
\text { announcements }\end{array}$ & $\begin{array}{l}\text { Difference between } \\
\text { expected and } \\
\text { announced } \\
\text { value/dummies }\end{array}$ & $\begin{array}{l}\text { ARMA with } \\
\text { heteroscedasticity } \\
\text { correction }\end{array}$ & Daily \\
\hline $\begin{array}{l}\text { Tivegna } \\
(2001)\end{array}$ & $\begin{array}{l}\text { Macroeconomic } \\
\text { announcements/Events, } \\
\text { opinions and statements }\end{array}$ & $\begin{array}{l}\text { Quantitative } \\
\text { variables/Ternary } \\
\text { dummies }\end{array}$ & $\begin{array}{l}\text { Multivariate GARCH } \\
\text { procedure based on } \\
\text { equation (1) }\end{array}$ & Twice daily \\
\hline $\begin{array}{l}\text { Fatum and } \\
\text { Hutchison } \\
\text { (2002) }\end{array}$ & $\begin{array}{l}\text { Statements and rumours on } \\
\text { ECB intervention }\end{array}$ & $\begin{array}{l}\text { Dummies for the } \\
\text { events }\end{array}$ & $\begin{array}{l}\text { OLS with } \\
\text { heteroscedasticity } \\
\text { correction }\end{array}$ & Daily \\
\hline $\begin{array}{l}\text { Andersen et } \\
\text { al. (2002) }\end{array}$ & $\begin{array}{l}\text { Macroeconomic } \\
\text { announcements }\end{array}$ & $\begin{array}{l}\text { Difference between } \\
\text { expected and } \\
\text { announced } \\
\text { value/dummies }\end{array}$ & $\begin{array}{l}\text { Mean modeled as } \\
\text { ARMA process }\end{array}$ & Five minute returns \\
\hline
\end{tabular}


Tivegna (2001) estimates a daily exchange rate model for both the German mark-dollar and the yen-dollar exchange rate. He distinguishes between scheduled (mostly quantitative) and nonscheduled (mostly qualitative) announcements. He identifies the following five categories in the latter category: market information and opinions, qualitative economic or political events, qualitative descriptions of quantitative events, policy statements by leading politicians, ministers or central bankers and official interventions in the foreign exchange markets. Tivegna concludes that statements by policy makers are an important market mover for both exchange rates. The coefficients found for political and market 'news' are, for example, much larger than those for 'news' on US macroeconomic developments.

Andersen and Bollerslev (1998) bring together three important factors that influence the volatility of the German mark-dollar exchange rate. The first category are calendar effects, the second category are macroeconomic announcements, while the final category are inter-daily volatility dependencies or ARCH effects (see Hsieh (1988) and Hsieh (1989)). One important conclusion is that the announcement effects are of secondary importance in explaining overall volatility. Announcements have significant effects shortly after they were made, but they explain less of the volatility than the other two factors. Almeida et al. (1998) support the conclusion of Andersen and Bollerslev (1998). They study the reaction of the German mark-dollar exchange rate to macroeconomic announcements using high frequency data. The announcements refer to U.S. and German data. Almeida et al. conclude that after three hours most of the effect from the announcement has disappeared. The effects are dwarfed by other events at the lower frequencies.

The study by Andersen et al. (2002) is similar to Andersen and Bollerslev (1998) in scope and modeling approach. The focus of this paper is, however, on the mean and not on the volatility of the exchange rate. Andersen et al. characterize the conditional mean of the spot rate of the U.S. dollar against five other currencies. Their model allows 'news' to affect the conditional mean as well as the conditional variance. They find that, in general, 'news' has a statistically significant effect on the exchange rate. The adjustment of the conditional mean in reaction to 'news' is very quick, whereas the adjustment in volatility is more gradual. There is also evidence that the sign of the 'news' matters for the response. Negative surprises have greater impact than positive surprises.

Finally, Galati and Ho (2001) and Fatum and Hutchison (2002) study 'news' effects for the euro-dollar exchange rate. Galati and Ho (2001) examine the impact of macroeconomic announcements. They investigate the relationship between scheduled macroeconomic 'news' and the daily change in the euro-dollar exchange rate, focusing on the impact of U.S. and European announcements during the first 2 years of EMU. These authors conclude that the unexpected parts of macroeconomic announcements can explain up till $10 \%$ of the daily variation in the euro-dollar rate. There is also evidence that the reaction to 'news' is asymmetric: good 'news' on the euro area has been ignored, while bad 'news' had an influence. This result is in line with De Grauwe's (2000) 
argument that given the great uncertainty about equilibrium levels of exchange rates, short-run movements tend to be driven by technical and chartist analysis. Sustained movements in one direction or another then lead to a search for fundamentals that explain these developments (framing). When the exchange rate changes, a search starts for fundamentals that can explain the observed change. In this way, a self-enforcing process can evolve: a declining euro is seen as evidence that there are problems in the economy of the euro area. These problems then reinforce the downward movement of the euro. So in a way, the causality is reversed: it is not the 'news' about fundamentals which drive the exchange rate, but the exchange rate determines the way the fundamentals are perceived.

Fatum and Hutchison (2002) study the effects of ECB intervention and intervention-related 'news' on the euro-dollar exchange rate. These authors use a regression approach to determine which 'news' variables had effect on the euro and use an event study methodology to assess whether the ECB interventions were successful. They use four categories of 'news': rumors of intervention by the ECB, statements by officials in support of the euro, statements by officials not supportive of the euro and reports of actual intervention. Rumors on intervention have a positive effect on the exchange rate and statements not supportive of the euro have a negative effect on the euro rate. Interestingly, there is an asymmetry between positive statements and negative statements: only the negative statements have persistent effects.

It follows from this analysis that the results as to which 'news' variables affect exchange rates differ substantially between studies. This is in line with the results of more structural models that often find parameter instability when relating so-called fundamentals to exchange rate developments. Also the survey of Cheung and Chinn (2000) suggests that the importance of macro-economic variables shifts over time. Another reason for the differences among the various studies may be the frequency of the data. If 'news' is quickly absorbed, low frequency analysis may not be able to detect any influence.

\section{Methodology}

\subsection{Modeling strategy}

It is well established that exchange rate series are I(1) processes. ${ }^{5}$ Therefore, we take the usual approach to investigate the properties of the first differences of the natural logs of the exchange rate series. Figure 1 plots this series. There is evidence of clustered volatility in the euro-dollar series. Therefore, it seems logical to use a GARCH type model as a starting point. As results with a simple GARCH $(1,1)$ model were not satisfying (non-negativity constraints in the variance equation were violated) we use the EGARCH model proposed by Nelson (1991).

\footnotetext{
${ }^{5}$ Unit root tests for the sample period (available on request) confirm this hypothesis.
} 
Figure 1: Daily changes in the log of the euro-dollar series between 1-1-1999 and 5-17-2002

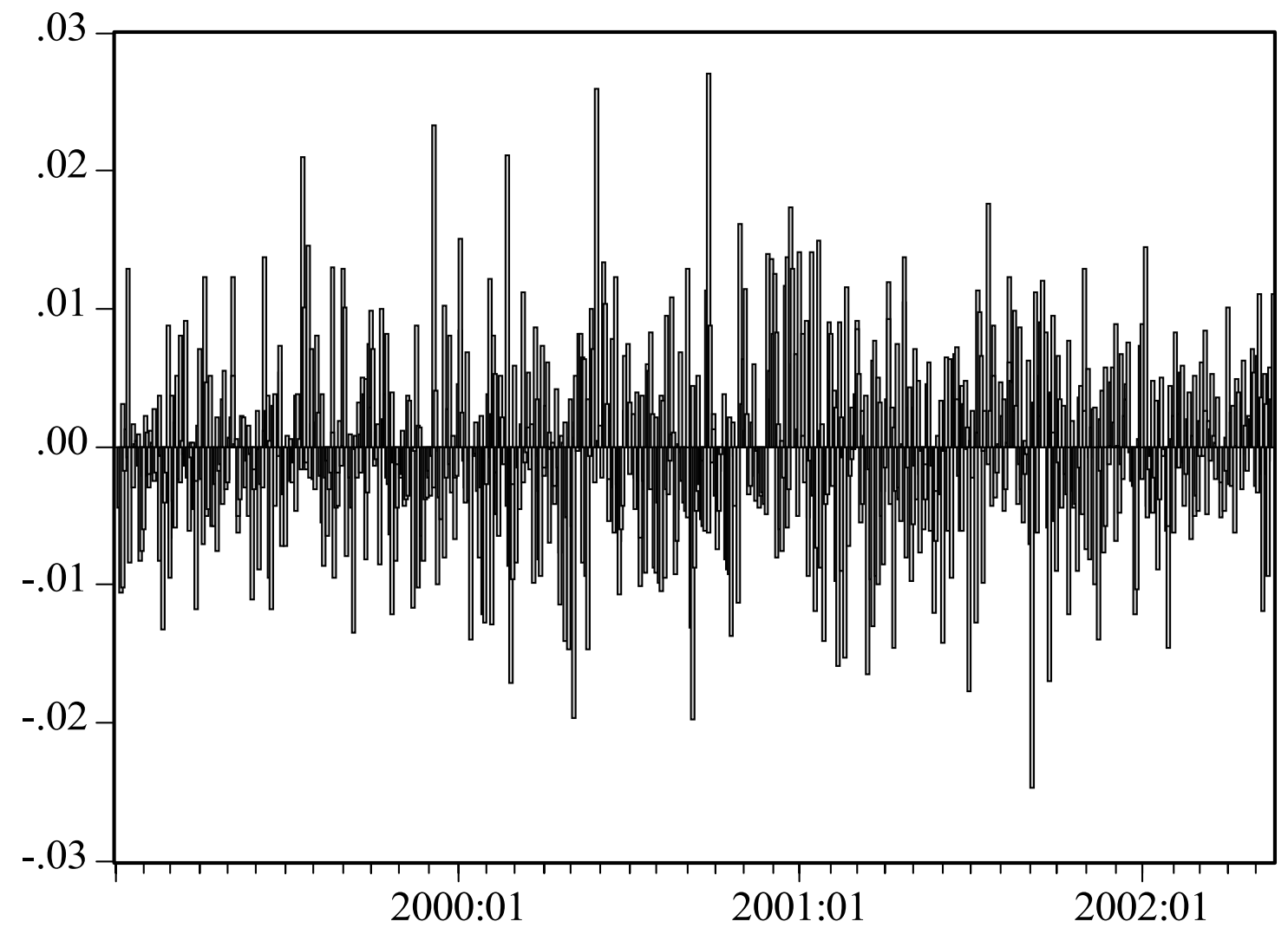

Our model looks as follows:

$$
\begin{gathered}
R_{t}=\beta_{0}+\sum_{i=1}^{n} \beta_{i} R_{t-i}+\sum_{k=1}^{K} \sum_{i=0}^{j} \beta_{k i} D_{k, t-i}+\beta_{w 1} D_{w 1}+\beta_{w 2} D_{w 2}+\beta_{w 3} D_{w 3}+\beta_{w 4} D_{w 4}+\varepsilon_{t}, \varepsilon_{t} \sim\left(0, h_{t}\right) \\
\log h_{t}=\delta_{0}+\delta_{1} \log h_{t-1}+\delta_{2}\left|\frac{\varepsilon_{t-1}}{h_{t-1}}\right|+\delta_{3} \frac{\varepsilon_{t-1}}{h_{t-1}}+\sum_{k=1}^{K} \sum_{i=0}^{j} \beta_{k i} D_{k, t-i}+\delta_{w 1} D_{w 1}+\delta_{w 2} D_{w 2}+\delta_{w 3} D_{w 3}+\delta_{w 4} D_{w 4}
\end{gathered}
$$

where $R_{t}$ represents the change in the natural logarithm of the exchange rate. Equation (2) has $n$ autoregressive terms and dummies for the weekdays $\left(D_{w 1} \ldots . . D_{w 4}\right)$ as control variables. ${ }^{6}$ The error term has a zero mean and a conditional variance $h_{t}$. The weekday dummies also enter the variance equation (see Hsieh 1988, 1989). $\mathrm{D}_{\mathrm{k}}$ are dummies that represent the ECB statements. These dummies enter the mean as well as the variance equation. Starting with this general approach, we then proceed to eliminate irrelevant variables. This means dropping nonsignificant variables in order to reach a parsimonious model. We use the Akaike information criterion to determine the appropriate number of lags.

\footnotetext{
${ }^{6}$ We also estimated this model using interest differentials as additional control variables. This did not change our basic results significantly. Results are available on request.
} 


\subsection{Organizing the statements to construct quantitative variables}

We will now discuss the construction of the variables $D_{k}$. This paper studies the effects of unexpected statements that are qualitative in nature. The literature suggests to use dummies for this purpose. These dummies can be used to test for effects whenever someone makes a statement. However, as Tivegna (2001) argues, the use of $(0,1)$ dummies could incorrectly lead to non-significant results as the effects of statements with a positive and negative content may cancel out. Therefore, he uses ternary variables that record whether a statement has an expected positive, neutral or negative effect on the exchange rate. Galati and Ho (2001) follow a similar approach.

Our approach is to start with simple $(0,1)$ occurrence dummies and then use dummies that take the content of a statement into account. We do not quite follow the method suggested by Tivegna (2001). Firstly, the interpretation of the coefficients in his approach is not straightforward. Therefore, we prefer to construct three dummies for each category of statements. The coefficients of these dummies can easily be interpreted. An additional benefit is that we can study whether there have been asymmetric reactions to 'news'. Secondly, assigning positive, neutral or negative values to statements on macro-economic variables is rather problematic. The statements are qualitative in nature and therefore difficult to interpret. Moreover, given the failure of empirical exchange rate models (Meese and Rogoff, 1983), we lack a simple method on how to categorize statements on macro-economic variables into positive, neutral and negative. We therefore start with a more neutral approach and record - where possible - whether an ECB official states that a macro-economic variable, for example inflation, will go up, down or remain the same. In doing this, we do not have to make controversial prior assumptions on the effects of these statements. Fortunately, in some cases we are able to specify our priors as to the effect of the statement.

We record the following basic characteristics of each statement: the day on which the statement was made, the person who made the statement and the content of the statement. We sampled all statements by ECB officials, as well as statements by officials of national central banks (NCBs) in the euro area. We identify eight different kind of statements that we expect to be relevant for the exchange rate (see Table 2). There are two main categories: monetary policy and the euro. There are five subcategories in the monetary policy category. First of all, there are statements on interest rates in the euro area. The remaining subcategories relate to the two-pillar strategy of the ECB. Firstly, there are statements on money growth in the euro area (first pillar). Secondly, there are statements on economic growth, inflation and the effects of the euro on inflation (second pillar).

For statements in the first category, we record whether according to the statement a variable, inflation say, will go up, or down, or will remain stable. It seems difficult to judge a priori what the effect of these statements will be. Nevertheless, economic theory suggests a few possible outcomes. Suppose that an ECB official indicates a bias towards higher rates. What may happen then? There are three possibilities (see also Harris and Zabka 1995 for a good discussion): the statement may have an 
effect either through an investor channel, an inflation channel and a growth channel. According to the first channel, there will be a positive relationship between interest rates and the exchange rate: higher rates makes buying European securities more attractive which will induce demand for euros. The second channel works through prices. If purchasing power parity is a good description of reality, higher interest rates will coincide with a fall in the euro. The final channel also predicts a negative relationship between interest rates and growth: higher interest rates hamper investments and thus hamper growth. Finally, note that we can generalize from this example on rates to the other four variables from the monetary policy category. Higher money growth may, for instance, lead to higher rates etc.

Table 2: Categories of ECB statements

\begin{tabular}{|ll|}
\hline $\begin{array}{l}\text { Category: } \\
\text { (1) Monetary policy }\end{array}$ & Contains statements on: \\
Interest rates & ECB interest rates \\
M3 & Growth of money supply \\
Economic growth & Real GDP growth in the euro area \\
Inflation & Inflation in the euro area \\
Pass-through & How the euro exchange rate will effect inflation in the \\
& euro area \\
& \\
(2) The euro & Expectations on the value of the euro \\
Future value of euro & The position of the euro in the monetary policy strategy \\
No target versus inflation & The possibility of intervention \\
Intervention &
\end{tabular}

The second main category that we distinguish is statements on the euro. Here we are able to assign a prior as to the expected effect on the euro-dollar exchange rate. The first subcategory under this heading contains statements expressing beliefs on the future direction of the exchange rate. In section 4 we will show that, during most of the time under consideration, the ECB expressed the view that the euro had potential to appreciate (positive effect). The second subcategory contains statements trying to explain the position of the euro in the ECB monetary policy strategy. There have been many of these statements in the sample period as the ECB has intensively communicated about its monetary policy strategy in recent years. ${ }^{7}$ Time and again, central bankers stressed that the external value of the euro was not an objective for monetary policy. Nevertheless, the extensive depreciation of the euro 
forced them to take the euro-dollar rate into account when making monetary policy decisions. This 'no target/inflation' problem may have led to confusion in currency markets. We characterize statements that stress the 'no target' part as negative, while statements that stress the possible effect on inflation are considered to have a positive effect. Finally, there are statements on the possibility of intervention. During the period under consideration, there has been a lot of speculation on possible intervention. In a similar vein as Fatum and Hutchison (2002), we test how markets have reacted to this news. Statements that suggest the possibility of intervention are expected to have a positive effect on the exchange rate, statements that deny possible intervention may have negative effects.

In order to see whether effects differ between (groups of) ECB officials, we construct dummies that for each day record whether or not a certain official made a statement on that day. In addition, we tried to construct variables that combine the results from these person dummies with those from the content of the statements. However, combining these two perspectives results in variables with very low variation and few data points (i.e., a lot of zeros out of a possible 880). Although this route is certainly very interesting, our data set is simply not rich enough to explore it further.

Finally, note that there is a difference in the number of observations between the statements series and the exchange rate series. Obviously, there is only one data point per day for the exchange rate series. However, there can be more than one statement per day. In addition, statements can be made during the weekend when trading activity is generally low. To synchronize the series, we add the statements made during the weekend to the scores for Monday. We also added up the different scores if we found more than one observation per trading day.

\subsection{Data sources}

The sample period ranges from January 4, 1999 until May 17, 2002, yielding 880 observations. The data set with ECB statements was collected from the Bloomberg News Service. ${ }^{8}$ This was done by scanning the daily headlines for keywords like ECB or names of ECB officials. We selected some 930 news reports in which ECB statements are reported. The criterion for including a statement is that it has to refer to the entire euro area. Statements on developments in individual countries were not included. We focus on unexpected statements, because we expect to find the greatest effects in these cases. For this reason, the monthly ECB press conferences are not included in our data set.

\footnotetext{
${ }^{7}$ Whether the ECB has been very successful in becoming transparent is another matter. See De Haan et al. (2003) for a detailed analysis of the transparency of the ECB.

${ }^{8}$ We kindly thank Het Financieele Dagblad for allowing us to use their Bloomberg terminal.
} 
The exchange rate and interest series are taken from Datastream. The exchange rates are New York noon spot rates (dollars per euro). This means that the cut off point for a trading day is 18.00 CET. ${ }^{9}$ The interest rates we use are one-month inter-bank rates.

\section{Description of the statement dummies}

\subsection{Central bankers}

Table 3 displays the statements dummies for three groups of central bankers and some selected individuals. National central bank presidents made statements on 336 trading days compared to a figure of 256 for the Executive Board of the ECB. We find 82 statements for Bundesbank officials (excluding the president of the German central bank). For no other European central bank do we find such a large amount of statements by its officials.

Table 3: Statement dummies for persons

\begin{tabular}{|ll|}
\hline & Total number of statements \\
Groups & \\
Executive Board & 256 \\
National Central Bank Presidents & 336 \\
Bundesbank officials (excluding president) & 82 \\
Total & 674 \\
& \\
Individuals & \\
Duisenberg & 92 \\
Bundesbank President & 179 \\
Tietmeyer ${ }^{\text {a) }}$ & 24 \\
Welteke b) & 155 \\
Trichet & 95 \\
\hline
\end{tabular}

Notes:

The numbers in this table show the number of trading days on which particular statements were made. ${ }^{\text {a) }}$ 04/01/1999 until $31 / 08 / 1999$

b) $01 / 09 / 1999$ until 17/05/2002

\footnotetext{
${ }^{9}$ Except during two weeks per year when U.S. and European D.S.T. are not synchronized. The cut off point then is 19.00 C.E.T.
} 
Table 3 also shows that the Bundesbank president has made more comments that any other ECB official. We find statements by either Tietmeyer or Welteke for 179 trading days, compared to 92 for Duisenberg and 95 for Trichet. Together with the 82 statements of other Bundesbank officials, in terms of total number of statements the German central bank ranks even higher than the Executive Board of the ECB. There are two possible explanations for this. First, financial markets may still attach greater importance to the Bundesbank than to the ECB. The ECB is a new institution that has not yet established a firm reputation. The German central bank in contrast, is a venerable institution that has proven its capability in monetary policy-making over the years. Financial market do not yet know how to judge the new situation and still attach great importance to Bundesbank statements for this reason. However, this explanation assumes that Bloomberg selects news in such a way, that the statements of Bundesbank officials receive most attention. This seems rather unlikely. Since it is Bloomberg's business to bring as much news as possible, we can safely assume that a bias in the news coverage does not exist.

Alternatively, it may be argued that the Bundesbank has not yet learnt to cope with its new role within the European System of Central Banks. For years, the Bundesbank has dominated monetary policy in Europe. All this has changed, however, and the Bundesbank had to step back in favor of the ECB. The fact that Bundesbank officials communicated so intensively to financial markets may reflect their difficulty in accepting this new situation.

\subsection{Content}

Table 4 presents our data referring to the content of the ECB statements. The numbers in the table show the number of trading days on which statements of a particular category were made. For example, there were neutral statements on interest rates on 173 out of the 881 trading days. There were indications of higher rates on 36 trading days and indications of lower rates on 12 trading days. It follows from Table 4 that the number of statements on money growth is relatively small compared to those on the second pillar of the monetary policy strategy. The statements on growth are generally positive (i.e., indicating that the outlook for growth is good), whereas the statements on inflation are more balanced. One reason could be, that statements on inflation may sooner lead to speculation on interest rate changes. This may cause ECB officials to be more careful when talking about inflation. Finally, there are statements on the pass-through of the depreciation of the euro into higher inflation on 100 trading days. Most of these statements (51) indicate higher risks for inflation. 
Table 4: The content of the ECB statements

\begin{tabular}{|lllll|}
\hline Monetary policy & Up & Neutral & Down & Total \\
Interest rates & & & & \\
M3 & 36 & 173 & 12 & 221 \\
Economic growth & 27 & 27 & 29 & 83 \\
Inflation & 194 & 25 & 35 & 254 \\
Pass-through & 79 & 111 & 90 & 280 \\
& 51 & 39 & 10 & 100 \\
& & & & \\
The euro & Positive & Neutral & Negative & Total \\
Future value of euro & 172 & 6 & 2 & 180 \\
No target versus inflation & 112 & 24 & 42 & 178 \\
Intervention & 17 & 22 & 18 & 57 \\
\hline
\end{tabular}

Notes: The numbers in this table show the number of trading days on which particular statements were made. Totals for Tables 3 and 4 do not add up, because one news item may refer to statement on more than one category.

There are many statements referring to the second main category. Of special interest is the subcategory 'future value of the euro'. ECB officials made positive statements on the euro on 172 trading days. Only 2 statements were negative and 6 were neutral, reflecting the efforts of the ECB to 'talk up the euro'.

The sub-category 'no target versus inflation' contains 178 statements. This large number of statements indicates that the ECB has made great efforts to explain the role of the euro in its monetary policy strategy. It is somewhat surprising that the majority of statements are positive. This may have led markets to believe there was some sort of target for the euro-dollar exchange rate.

Finally, we recorded statements on (possible) intervention for 57 trading days. Of these statements 17 raised the probability of intervention, 22 were neutral and 18 lowered the probability of intervention by the ECB. 


\section{Results}

\subsection{Statements of central bankers}

The best EGARCH specification for the euro-dollar exchange rate is reported in the first column of Table 5. The weekday dummies in the mean equation were always non-significant, so they are excluded in the remainder of the analysis. We also found that adding more than one autoregressive term in the mean equation was not necessary on the basis of the AIC. For the variance equation we prefer an EGARCH(1,1) model. Adding more EGARCH terms did not add much to the model. A robust result is the lower conditional variance on the Monday. The dummy for Friday is also significant, but the coefficient displays more variation between different specifications. ${ }^{10}$

Next, we added dummies reflecting whether there was a statement by any ECB official or not. The second column of Table 5 presents the regression results. We do not find any significant effect of these statements for the mean of the exchange rate. However, there is a significant increase in volatility after the day the statement was made. Volatility is approximately $27 \%$ higher in these cases. ${ }^{11}$ Interestingly, this coincides with the findings of Cheung and Chinn (2000) for central bank interventions: forex traders believe that interventions mainly affect the volatility of exchange rates.

Do these conclusions hold for different groups of ECB officials as well? Our results indicate that for Executive Board members there is also evidence for an increase in volatility (column 3 of Table 5). The coefficient of the lagged value of the statement dummy is 0.21 , indicating, once again, an increase in volatility of $27 \%$. Statements by Bundesbank officials (excluding the president) have no effect on volatility, but there are temporary and off-setting effects on the mean (column 4 of Table 5). There is an appreciation of $0.17 \%$ on the trading day itself and a subsequent depreciation of $0.12 \%$ on the day thereafter. According to a Wald test, the total effect turns out to be not significantly different from zero.

\footnotetext{
${ }^{10}$ Given the exponential specification a coefficient in the variance equation that is smaller (larger) than zero indicates lower (higher) variance.

${ }^{11} 10^{0.21} \approx 1.62$. We use the standard deviation to measure volatility, so volatility increases with $(\sqrt{ } 1.62)-1$
} 
Table 5: Results for groups of ECB officials

\begin{tabular}{|c|c|c|c|c|}
\hline & (1) & (2) & (3) & (4) \\
\hline & $\begin{array}{c}\text { No statement dummies, } \\
\text { EGARCH model }\end{array}$ & All & Executive Board & $\begin{array}{c}\text { Bundesbank officials } \\
\text { (excl. President) }\end{array}$ \\
\hline $\begin{array}{l}\text { Mean equation } \\
\text { (equation } 3 \text { ) }\end{array}$ & & & & \\
\hline Constant & -0.00 & -0.00 & -0.00 & -0.00 \\
\hline $\operatorname{AR}(1)$ & 0.03 & 0.03 & 0.03 & 0.04 \\
\hline Statement dummies & - & - & - & $0.0016 * * *$ \\
\hline $\begin{array}{l}\text { Statement dummies } \\
\text { (1st lag) }\end{array}$ & - & - & - & $-0.0012 *$ \\
\hline $\begin{array}{l}\text { Variance equation } \\
\text { (equation 4) }\end{array}$ & & & & \\
\hline Constant & $-10.45 * * *$ & $-8.47 * * *$ & $-9.67 * * *$ & $-10.15^{* * *}$ \\
\hline Statement dummies & & - & - & - \\
\hline $\begin{array}{l}\text { Statement dummies } \\
\text { (1st lag) }\end{array}$ & & $0.21 *$ & $0.21 *$ & - \\
\hline$\delta 1$ & -0.05 & 0.16 & 0.01 & -0.04 \\
\hline$\delta 2$ & $-0.18^{*}$ & -0.14 & $-0.17 *$ & $-0.19 *$ \\
\hline$\delta 3$ & 0.01 & 0.01 & 0.01 & 0.00 \\
\hline Monday & $-0.50 * * *$ & $-0.62 * * *$ & $-0.56^{* * *}$ & $-0.53 * * *$ \\
\hline Friday & $0.27 *$ & - & $-0.27^{*}$ & $-0.27^{*}$ \\
\hline Adjusted $\mathrm{R}^{2}$ & -0.01 & -0.01 & -0.01 & -0.00 \\
\hline DW & 1.98 & 1.98 & 1.98 & 1.98 \\
\hline
\end{tabular}

Notes:

This table shows EGARCH models for the euro-dollar exchange rate (equations 3 and 4 in the main text). In column (1) no statement dummies are included. In column (2) all statements by ECB officials are taken up. In column (3) only statements by members of the Executive Board are included, while in column (4) statements by officials of the German central bank (excl. the president of the Bundesbank) are shown. Bollerslev-Woolridge robust standard errors and covariance are used. $* / * * / * * *$ denotes significance at the $10 / 5 / 1 \%$ level, respectively. 
Next, we added occurrence dummies for all 18 members of the ECB Governing Council. Initially, we used all dummies in the estimation. We then proceeded to eliminate non-significant dummies. Not entirely unexpected, statements by Duisenberg, the Bundesbank president, and Trichet turn out to be of importance. Table 6 shows the results. After eliminating non-significant variables and using the AIC to determine the appropriate number of lags, we find the best specification only has statement dummies in the mean equation. Statements by Duisenberg and the Bundesbank president coincide with a depreciation of the euro. In contrast, statements by Trichet coincide with an appreciation.

Table 6: Results for statements by Duisenberg, Bundesbank president and Trichet

\begin{tabular}{lc} 
Mean equation & -0.00 \\
Constant & 0.03 \\
AR(1) & $-0.0012^{* *}$ \\
Duisenberg & - \\
Duisenberg (1st lag) & $-0.0013^{* *}$ \\
Bundesbank president & \\
Bundesbank president (1st lag) & \\
Trichet & $0.0015^{* *}$ \\
Trichet (1st lag) & \\
& \\
Variance equation & \\
Constant & - \\
Bundesbank president (1st lag) & - \\
Trichet & - \\
Trichet (1st lag) & - \\
$\delta 1$ & $0.39^{* * *}$ \\
$\delta 2$ & -15 \\
$\delta 3$ & -0.14 \\
Monday & 0.01 \\
Friday & $-0.69^{* * *}$ \\
Adjusted $\mathrm{R}^{2}$ & - \\
DW & 0.00 \\
\hline
\end{tabular}

Notes: This table shows EGARCH models for the euro-dollar exchange rate (equations 3 and 4 in the main text). BollerslevWoolridge robust standard errors and covariance are used. */**/*** denotes significance at the $10 / 5 / 1 \%$ level, respectively. 


\subsection{Effects of statements on intervention, the euro and inflation}

We now turn to the content of the statements. As a first approach, we use occurrence dummies to test for effects of statements, independent of whether the statement was positive, neutral or negative. We analyze two cases. In the first regression we include dummies for statements on interest rates and the euro category (statements on the future direction of the exchange rate, statements trying to explain the position of the euro in the ECB monetary policy strategy, and statements on possible interventions; see bottom half of Table 2). In the second regression we have replaced the dummy for statements on interest rates by dummies for statements on the first and second pillar of the monetary policy strategy of the ECB (statements on money growth, inflation, and the pass-through of the euro depreciation in inflation). We present two regressions because of a possible simultaneity problem: statements on variables like inflation and growth may influence the exchange rate as well as trigger statements on rates. By estimating two equations, we try to separate these effects. The results are reported in Table 7.

In the first regression, the dummy for statements on possible intervention is the only variable that is of importance in the mean equation (column 1 of Table 7). Interestingly, statements on possible intervention initially cause a depreciation of the euro. The next day, the exchange rate appreciates with the same amount. A Wald test confirms that the total effect over the two day period is not significantly different from zero. The coefficient of the dummy reflecting statements on the future potential of the euro is not significant in the mean equation. This leads us to conclude that the ECB has not been successful in 'talking up' the euro. This result is in line with the findings of Fatum and Hutchison (2002). However, statements on the future value of the euro have a significant effect in the variance equation. Volatility is $30 \%$ lower on the day that statements on the euro are made. However, the day after the statement was made volatility increases with $80 \%$.

These results for our second regression are comparable to those of the first. The difference is that for intervention we now only find effects for the lagged value of the intervention dummy. This also means that over the two day period, the effect is significantly different from zero. This result is in line with the findings of Fatum and Hutchison (2002) on interventions. However, these authors have a dummy reflecting the presence of rumors on interventions, while our dummy refers to statements of ECB officials on interventions, which may not be the same.

In addition, we find a small effect of statements on inflation (appreciation of $0.07 \%$ ) and statements on pass-through of changes in the euro-dollar rate into inflation (depreciation of $0.21 \%$ ). The coefficient of the dummy for statements on the future potential of the euro is significant in the variance equation. There is also evidence that statements on the trade-off between the euro as a target and inflation have led to lower volatility. 
Table 7: Results using dummies for content of statements

\begin{tabular}{|lcc|}
\hline & $(1)$ & $(2)$ \\
Mean equation & & \\
Constant & & \\
AR(1) & -0.00 & -0.00 \\
Inflation & 0.02 & 0.03 \\
Pass-through & - & $0.0007^{*}$ \\
Intervention & - & $-0.0021^{* * *}$ \\
Intervention(1st lag) & $-0.0016^{*}$ & - \\
& $0.0016^{*}$ & $0.0020^{*}$ \\
Variance equation & & \\
Constant & & \\
Pass-through & $-5.83^{* * *}$ & $-6.89^{* * *}$ \\
Future euro & - & $0.55^{* * *}$ \\
Future euro (1st lag) & $-0.32^{* *}$ & $-0.33^{* *}$ \\
No target versus inflation & $0.52^{* * *}$ & $0.49^{* * *}$ \\
$\delta 1$ & - & $-0.28^{* *}$ \\
$\delta 2$ & $0.41^{* *}$ & $0.29^{*}$ \\
$\delta 3$ & -0.13 & $-0.17^{* *}$ \\
Monday & 0.03 & 0.01 \\
Friday & $-0.65^{* * *}$ & $-0.57^{* * *}$ \\
Adjusted $\mathrm{R}^{2}$ & - & $-0.25^{*}$ \\
DW & -0.01 & -0.01 \\
& 1.98 & 1.98 \\
\hline
\end{tabular}

Notes:

This table shows EGARCH models for the euro-dollar exchange rate (equations 3 and 4 in the main text). Column (1) reports the results for the specification with dummies for statements on interest rates and dummies for statements on the future direction of the exchange rate, statements trying to explain the position of the euro in the ECB monetary policy strategy, and statements on possible interventions. Column (2) reports the results if the dummy for statements on interest rates is replaced by dummies for statements on the two-pillar strategy of the euro (money growth, inflation, growth and pass-through of euro depreciation in inflation). Only the significant coefficients are shown. Bollerslev-Woolridge robust standard errors and covariance are used. $* / * * / * * *$ denotes significance at the $10 / 5 / 1 \%$ level, respectively. 
Finally, we have used dummies that control for the message contained in a statement. This allows us to make distinction between positive, neutral and negative statements. As before, we use two regressions. The results are shown in Table 8.

The first column shows that there are effects from statements on interest rates and on the euro as a target versus inflation on the level of the exchange rate. Statements that indicate a rate rise are followed by a depreciation of $0.36 \%$ the next day. This negative reaction may be explained by the negative effect of an interest rate rise on economic growth. The results from the target versus inflation category are interesting. Statements we classify as neutral coincide with a small depreciation $(0.16 \%)$. This may indicate that these types of statements have led to negative sentiments on currency markets. Negative statements in this category (stressing that the euro is not a target) coincide with an appreciation $(0.13 \%)$.

In the variance equation we find that volatility was lower on days during which positive statements on the euro were made. However, the next day volatility was almost $70 \%$ higher. Both neutral and negative statements on the role of the euro in the ECB monetary policy strategy coincide with lower volatility. Statements raising the possibility of intervention lead to higher volatility during the day, as may be expected, while the next day volatility is lower. Neutral statements on intervention coincide with lower volatility, but the next day volatility shows a large increase.

In the second regression we find significant coefficients in the mean equation for M3 growth, inflation, pass-through and intervention. Higher money growth seems to have a negative effect on the exchange rate as it depreciates with $0.28 \%$. Lower inflation produces positive effects: the euro appreciates by $0.14 \%$. Neutral statements on pass-through coincide with a depreciation of $0.18 \%$. Finally, merely talking about intervention can lead to results: the exchange rates appreciates with $0.25 \%$ after the day positive statements on intervention were made.

All variables from the monetary policy main category enter the variance equation. Statements on higher money growth and neutral statements on growth initially lead to lower volatility, whereas statements on inflation and pass-through initially lead to higher volatility. In the cases of growth and pass-through there is a contrary effect on the next day. The results for statements belonging to the euro category are similar to those from the first regression. One difference is that positive statements on intervention no longer lead to changes in volatility.

So overall, we find that an asymmetric reaction to 'news': the market reacts differently to positive and negative 'news'. This is in line with the findings by Galati and Ho (2001), Fatum and Hutchison (2002), and Andersen et al. (2002). 
Table 8: Results using dummies that take content of message into account

\begin{tabular}{|c|c|c|}
\hline & (1) & (2) \\
\hline \multicolumn{3}{|l|}{ Mean equation } \\
\hline Constant & -0.00 & $-0.00 * *$ \\
\hline $\operatorname{AR}(1)$ & 0.02 & 0.02 \\
\hline Rates up (1st lag) & $-0.0036 * * *$ & - \\
\hline M3 up (1st lag) & - & $-0.0028 * * *$ \\
\hline Inflation down & - & $0.0014 * *$ \\
\hline Pass-through neutral & - & $-0.0018 * * *$ \\
\hline No target versus inflation neutral & $-0.0016^{* *}$ & - \\
\hline No target versus inflation negative (1st lag) & $0.0013 *$ & - \\
\hline Intervention positive (1st lag) & - & $0.0025^{*}$ \\
\hline \multicolumn{3}{|l|}{ Variance equation } \\
\hline Constant & $-4.64 * * *$ & $-4.54 * * *$ \\
\hline M3 up & - & $-0.91 * * *$ \\
\hline Growth neutral & - & $-0.86 * * *$ \\
\hline Growth neutral (1st lag) & - & $1.09 * * *$ \\
\hline Inflation up & - & $0.47 * * *$ \\
\hline Pass-through up & - & $0.65 * *$ \\
\hline Pass-through up (1st lag) & - & $-0.54 * *$ \\
\hline Euro up & $-0.37 * *$ & $-0.41 * * *$ \\
\hline Euro up (1st lag) & $0.46^{* * *}$ & $0.51 * * *$ \\
\hline No target vs inflation neutral & $-0.63 * * *$ & $-0.86 * * *$ \\
\hline No target vs inflation neutral (1st lag) & - & $0.63 * *$ \\
\hline No target vs inflation negative & $-0.52 * * *$ & - \\
\hline Intervention positive & $0.75 * *$ & - \\
\hline Intervention positive (1st lag) & $-0.73 *$ & - \\
\hline Intervention neutral & $-0.56^{* *}$ & $-0.81 * * *$ \\
\hline Intervention neutral (1st lag) & $1.13 * * *$ & $1.22 * * *$ \\
\hline$\delta 1$ & $0.52 * * *$ & $0.54 * * *$ \\
\hline$\delta 2$ & $-0.18 * *$ & $-0.16^{* *}$ \\
\hline$\delta 3$ & 0.03 & -0.00 \\
\hline Monday & $-0.68 * * *$ & $-0.79 * * *$ \\
\hline Adjusted $\mathrm{R}^{2}$ & -0.01 & -0.01 \\
\hline DW & 1.94 & 1.99 \\
\hline
\end{tabular}


Notes:

This table shows EGARCH models for the euro-dollar exchange rate (equations 3 and 4 in the main text). Column (1) reports the results for the specification with dummies for statements on interest rates and dummies for statements on the future direction of the exchange rate, statements trying to explain the position of the euro in the ECB monetary policy strategy, and statements on possible interventions. Column (2) reports the results if the dummy for statements on interest rates is replaced by dummies for statements on the two-pillar strategy of the euro (money growth, inflation, growth and pass-through of euro depreciation in inflation). Only the significant coefficients are shown. Bollerslev-Woolridge robust standard errors and covariance are used. $* / * * / * * *$ denotes significance at the $10 / 5 / 1 \%$ level, respectively. 


\section{Concluding comments}

Our results suggest that the effects of ECB statements on the level of the exchange rate are comparatively small. Moreover, the effects are often not persistent: statements rarely have significant effects over the two day period after the statement. However, in the case of volatility, ECB statements have had considerable impact. Firstly, there is evidence that for the ECB officials as a group volatility increases after policy statements are made. Secondly, more statement dummies show up in the variance equation than in the mean equation. Thirdly, effects can be quite large. Our results indicate that volatility may rise with as much as $25 \%$ after ECB statements. Our conclusion is, therefore, that central banks should be careful with their comments, as in general volatility increases. One implication may be, that in order to secure this, communication should be more centralized. National central banks should step back and let the ECB president handle the communication to financial markets.

Efforts of the ECB to 'talk up' the euro have been without result. Statements that were intended to bolster up the external value of the euro did not lead to an appreciation, but only led to higher volatility. As volatility increases uncertainty, the advice for the ECB seems to be not to use this particular strategy again in the future. In contrast, communications about intervention may have some effect on the level of the exchange rate. If a central bank wants to intervene, talking about it before the intervention takes place may therefore be worthwhile considering.

We find evidence that certain statements on monetary policy have had influence on the level of the exchange rate. In most cases the results show a negative relationship between interest rates and the exchange rates and between inflation and the exchange rate. For example, indications of a rate rise lead to a depreciation on the day following the statement. This may be seen as evidence for either an inflation channel or a growth channel. Finally, there is evidence of asymmetric reactions to 'news'. Markets respond differently to positive or negative news from the same category. 


\section{References}

Almeida, A., C.A. Goodhart and R. Payne (1998), The Effects of Macroeconomic News on High Frequency Exchange Rate Behaviour, Journal of Financial and Quantitative Analysis 33, 283-408.

Andersen, T.G., T. Bollerslev, F.X. Diebold and C. Vega (2002), Micro Effects of Macro Announcements: Real-Time Price Discovery in Foreign Exchange, American Economic Review (forthcoming).

Andersen, T.G. and T. Bollerslev (1998), Deutsche Mark-Dollar Volatility: Intraday Activity Patterns, Macroeconomic Announcements, and Longer Run Dependencies, Journal of Finance 53, 219-265.

Cheung, Y-W. and M.Z. Chinn (2001), Currency traders and exchange rate dynamics: a survey of the US market, Journal of International Money and Finance 20, 439-471.

Cheung, Y-W. and F. Westermann (2001), Equity dynamics before and after the introduction of the euro: a note, CESifo Working Paper No. 420.

DeGenarro, R.P. and R.E. Shrieves (1997), Public information releases, private information arrival and volatility in the foreign exchange market, Journal of Empirical Finance 4, 295-315.

De Grauwe, P. (2000), Exchange Rates in Search of Fundamentals: The Case of the Euro-Dollar Rate, International Finance 3 (3), 329-56.

De Grauwe, P., H. Dewachter and M. Embrechts (1993), Exchange Rate Theory. Chaotic models of foreign exchange markets, Oxford: Blackwell.

De Haan, J., S.C.W. Eijffinger and S. Waller (2003), The ECB: Decentralization, Credibility and Transparency, Cambridge (MA): MIT Press (forthcoming).

Ederington, L.H. and J.H. Lee (1993), How markets process information: news releases and volatility, Journal of Finance 4, 1161-1191.

Evans, M.D.D. and R.K. Lyons (2003), How is macro news transmitted to exchange rates?, NBER Working Paper No. 9433. 
Eijffinger, S.C.W. and J. De Haan (2000), European Monetary and Fiscal Policy, Oxford: Oxford University Press.

Fatum, R. and M.M. Hutchison (2002), ECB Foreign Exchange Intervention and the EURO: Institutional Framework, News, and Intervention, Open Economies Review 13, 413-425.

Fatum, R. and M.M. Hutchison (2003), Is Sterilized Foreign Exchange Intervention Effective After All? An Event Study Approach, forthcoming in: The Economic Journal.

Frenkel, J.A. (1981), Flexible exchange rates, prices, and the role of 'news': lessons from the 1970s, Journal of Political Economy 89, 665-705.

Frenkel, M. C. Pierdzioch, and G. Stadtmann (2001), The Foreign Exchange Market Interventions of the European Central Bank, Banca Nazionale del Lavoro Quarterly Review, No. 218, 249-87.

Galati, G. and C. Ho (2001), Macroeconomic news and the euro/dollar exchange rate, Bank for International Settlements Working Paper No 105.

Goodhart, C.A.E., S.G. Hall, S.G.B. Henry and B. Pesaran (1993), News effects in a high-frequency model of the sterling-dollar exchange rate, Journal of Applied Econometrics 8, 1-13.

Hakkio, C.S. and D.K. Pearce (1985), The reaction of exchange rates to economic news, Economic Inquiry 23, 621-635.

Harris, E.S. and N.M. Zabka (1995), The Employment Report and the Dollar, Current Issues in Economics and Finance 1 Federal Reserve Bank of New York, November 1995.

Hsieh, D.A. (1988), The statistical properties of daily foreign exchange rates: 1974-1983, Journal of International Economics 24, 129-145.

Hsieh, D.A. (1989), Modeling heteroscedasticity in daily foreign-exchange rates, Journal of Business \& Economic Statistics 7, 307-317.

Ito, T. and V.V. Roley (1987), News from U.S and Japan: Which moves the yen/dollar exchange rate?, Journal of Monetary Economics 19, 255-277. 
Meese, R.A. and K. Rogoff (1983), Empirical exchange rate models of the seventies: do they fit out of sample?, Journal of International Economics, 14, pp. 3-24.

Nelson, D.B. (1991), Conditional heteroskedasticity in asset returns: a new approach, Econometrica, 59, pp. 347-370.

Rigobon, R. and B. Sack (2002), The impact of monetary policy on asset prices, NBER Working Paper No. 8794.

Sarno, L. and M.P. Taylor (2001), Official Intervention in the Foreign Exchange Market: Is It Effective and, If So, How Does It Work, Journal of Economic Literature 39, 839-68.

Tivegna, M. (2001), News and Dollar Exchange Rate Dynamics, Università di Roma Tor Vergata Quaderni Ceis No. 131. 


\title{
CESifo Working Paper Series
}

\author{
(for full list see www.cesifo.de)
}

860 Haizhou Huang, Dalia Marin, and Chenggang Xu, Financial Crisis, Economic Recovery and Banking Development in Former Soviet Union Economies, February 2003

861 Pedro Cardoso and Bernard M.S. van Praag, How Sustainable Are Old-age Pensions in a Shrinking Population with Endogenous Labour Supply?, February 2003

862 Volker Meier, Efficient Transfer of Aging Provisions in Private Health Insurance, February 2003

863 Edward Castronova, Theory of the Avatar, February 2003

864 Robert S. Chirinko, Hans van Ees, Harry Garretsen, and Elmer Sterken, Investor Protections and Concentrated Ownership: Assessing Corporate Control Mechanisms in the Netherlands, February 2003

865 Bernard M.S. van Praag and Pedro Cardoso, The Mix Between Pay-as-you-go and Funded Pensions and what Demography has to do with it, February 2003

866 Ernst Fehr, Urs Fischbacher, Bernhard von Rosenbladt, Jürgen Schupp, and Gert G. Wagner, A Nation-Wide Laboratory. Examining Trust and Trustworthiness by Integrating Behavioral Experiments into Representative Survey, February 2003

867 Frank Heinemann, The Inflationary Impact of Wage Indexation, February 2003

868 Eytan Sheshinski, Bounded Rationality and Socially Optimal Limits on Choice in a Self-Selection Model, February 2003

869 M. Hashem Pesaran, Estimation and Inference in Large Heterogenous Panels with Cross Section Dependence, February 2003

870 Luis H. R. Alvarez and Erkki Koskela, On the Tree-Cutting Problem under Interest Rate and Forest Value Uncertainty, February 2003

871 Norbert Berthold and Rainer Fehn, Unemployment in Germany: Reasons and Remedies, February 2003

872 Clemens Fuest, Bernd Huber, and Philipp Tilleßen, Tax Policy and Entrepreneurship in the Presence of Asymmetric Information in Capital Markets, February 2003

873 Eytan Sheshinski, Optimum and Risk-Class Pricing of Annuities, February 2003

874 Willi Leibfritz, Paul O'Brien and Jean-Christophe Dumont, Effects of Immigration on Labour Markets and Government Budgets - An Overview, February 2003 
875 M. Hashem Pesaran and Allan Timmermann, How Costly is it to Ignore Breaks when Forecasting the Direction of a Time Series?, February 2003

876 Thorvaldur Gylfason and Gylfi Zoega, Education, Social Equality and Economic Growth: A View of the Landscape, February 2003

877 Robin Boadway and Jean-François Tremblay, Public Economics and Startup Entrepreneurs, February 2003

878 Erkki Koskela and Roope Uusitalo, The Un-Intended Convergence: How the Finnish Unemployment Reached the European Level, February 2003

879 Robert Fenge and Volker Meier, Pensions and Fertility Incentives, February 2003

880 Eytan Sheshinski, Note on Income Taxation and Occupational Choice, February 2003

881 A B Atkinson, Income Inequality in OECD Countries: Data and Explanations, February 2003

882 Thomas Gehrig and Rune Stenbacka, Venture Cycles: Theory and Evidence, February 2003

883 Ralf Becker and Thomas Hellmann, The Genesis of Venture Capital - Lessons from the German Experience, March 2003

884 Eytan Sheshinski, Note on the Optimum Pricing of Annuities, March 2003

885 Paul De Grauwe and Magdalena Polan, Globalisation and Social Spending, March 2003

886 F. van der Ploeg, Do Social Policies Harm Employment and Growth?, March 2003

887 Mirjam van Praag, Initial Capital Constraints Hinder Entrepreneurial Venture Performance: An empirical analysis, March 2003

888 Bernard Steunenberg, Coordinating Sectoral Policymaking: Searching for Countervailing Mechanisms in the EU Legislative Process, March 2003

889 Eytan Sheshinski, Optimum Delayed Retirement Credit, March 2003

890 Frederick van der Ploeg, Rolling Back the Public Sector - Differential effects on employment, investment and growth, March 2003

891 Paul De Grauwe and Marc-Alexandre Sénégas, Monetary Policy in EMU when the Transmission is Asymmetric and Uncertain, March 2003

892 Steffen Huck and Kai A. Konrad, Strategic Trade Policy and the Home Bias in Firm Ownership Structure, March 2003

893 Harry Flam, Turkey and the EU: Politics and Economics of Accession, March 2003 
894 Mathias Hoffmann and Ronald MacDonald, A Re-examination of the Link between Real Exchange Rates and Real Interest Rate Differentials, March 2003

895 Badi H. Baltagi, Espen Bratberg, and Tor Helge Holmås, A Panel Data Study of Physicians' Labor Supply: The Case of Norway, March 2003

896 Dennis C. Mueller, Rights and Citizenship in the European Union, March 2003

897 Jeremy Edwards, Gains from Trade in Tax Revenue and the Efficiency Case for Trade Taxes, March 2003

898 Rainer Fehn and Thomas Fuchs, Capital Market Institutions and Venture Capital: Do They Affect Unemployment and Labour Demand?, March 2003

899 Ronald MacDonald and Cezary Wójcik, Catching Up: The Role of Demand, Supply and Regulated Price Effects on the Real Exchange Rates of Four Accession Countries, March 2003

900 R. Selten, M. Schreckenberg, T. Pitz, T. Chmura, and S. Kube, Experiments and Simulations on Day-to-Day Route Choice-Behaviour, April 2003

901 Stergios Skaperdas, Restraining the Genuine Homo Economicus: Why the Economy Cannot be Divorced from its Governance, April 2003

902 Yin-Wong Cheung, Menzie D. Chinn, and Antonio Garcia Pascual, What Do We Know about Recent Exchange Rate Models? In-Sample Fit and Out-of-Sample Performance Evaluated, April 2003

903 Mika Widgrén, Enlargements and the Principles of Designing EU - Decision-Making Procedures, April 2003

904 Phornchanok Cumperayot, Dusting off the Perception of Risk and Returns in FOREX Markets, April 2003

905 Kai A Konrad, Inverse Campaigning, April 2003

906 Lars P. Feld and Stefan Voigt, Economic Growth and Judicial Independence: Cross Country Evidence Using a New Set of Indicators, April 2003

907 Giuseppe Bertola and Pietro Garibaldi, The Structure and History of Italian Unemployment, April 2003

908 Robert A.J. Dur and Otto H. Swank, Producing and Manipulating Information, April 2003

909 Christian Gollier, Collective Risk-Taking Decisions with Heterogeneous Beliefs, April 2003

910 Alexander F Wagner, Mathias Dufour, and Friedrich Schneider, Satisfaction not Guaranteed - Institutions and Satisfaction with Democracy in Western Europe, April 2003 
911 Ngo Van Long, Raymond Riezman, and Antoine Soubeyran, Trade, Wage Gaps, and Specific Human Capital Accumulation, April 2003

912 Andrea Goldstein, Privatization in Italy 1993-2002: Goals, Institutions, Outcomes, and Outstanding Issues, April 2003

913 Rajshri Jayaraman and Mandar Oak, The Signaling Role of Municipal Currencies in Local Development, April 2003

914 Volker Grossmann, Managerial Job Assignment and Imperfect Competition in Asymmetric Equilibrium, April 2003

915 Christian Gollier and Richard Zeckhauser, Collective Investment Decision Making with Heterogeneous Time Preferences, April 2003

916 Thomas Moutos and William Scarth, Some Macroeconomic Consequences of Basic Income and Employment Subsidies, April 2003

917 Jan C. van Ours, Has the Dutch Miracle Come to an End?, April 2003

918 Bertil Holmlund, The Rise and Fall of Swedish Unemployment, April 2003

919 Bernd Huber and Marco Runkel, Optimal Design of Intergovernmental Grants under Asymmetric Information, April 2003

920 Klaus Wälde, Endogenous Business Cycles and Growth, April 2003

921 Ramon Castillo and Stergios Skaperdas, All in the Family or Public? Law and Appropriative Costs as Determinants of Ownership Structure, April 2003

922 Peter Fredriksson and Bertil Holmlund, Improving Incentives in Unemployment Insurance: A Review of Recent Research, April 2003

923 Bernard M.S. van Praag and Adam S. Booij, Risk Aversion and the Subjective Time Discount Rate: A Joint Approach, April 2003

924 Yin-Wong Cheung, Dissecting the PPP Puzzle: The Unconventional Roles of Nominal Exchange Rate and Price Adjustment, April 2003

925 Ugo Trivellato and Anna Giraldo, Assessing the 'Choosiness' of Job Seekers. An Exploratory Approach and Evidence for Italy, April 2003

926 Rudi Dornbusch and Stanley Fischer, International Financial Crises, April 2003

927 David-Jan Jansen and Jakob de Haan, Statements of ECB Officials and their Effect on the Level and Volatility of the Euro-Dollar Exchange Rate, April 2003 